\title{
Maize growth in response to Azospirillum brasilense, Rhizobium tropici, molybdenum and nitrogen
}

\author{
Angelita A. C. Picazevicz ${ }^{1}$, Jorge F. Kusdra ${ }^{1} \&$ Andréia de L. Moreno $^{1}$ \\ ${ }^{1}$ Universidade Federal do Acre/Centro de Ciências Biológicas e da Natureza. Rio Branco, AC. E-mail: angelitaacoutinho@gmail.com (Corresponding \\ author); kusdra@globo.com; andreiatantalo.lider@gmail.com
}

Key words:
Zea mays
PGPR
diazotrophic microorganisms
co-inoculation
BNF

\section{Palavras-chave:}

Zea mays

RPCPs

microrganismos diazotróficos coinoculação

FBN

\begin{abstract}
A B S T R A C T
The objective of this research was to evaluate the effect of Azospirillum brasilense, Rhizobium tropici, nitrogen $(\mathrm{N})$ and molybdenum (Mo) fertilization on maize growth. The experiment was carried out in a greenhouse from October to November 2015, in a completely randomized design, in $2 \times 2 \times 2 \times 5$ factorial scheme, with 5 replicates, corresponding to the absence and presence of Azospirillum brasilense, Rhizobium tropici, $\mathrm{N}\left(30 \mathrm{~kg} \mathrm{ha}^{-1}\right)$ and five Mo doses (0, 7.5, 15.0, 22.5 and $\left.30.0 \mathrm{~g} \mathrm{ha}^{-1}\right)$. The analyzed variables were: plant height, basal stem diameter, dry biomass of shoots, roots, total and $\mathrm{N}$ accumulated in the shoots. There was double or triple interaction between $\mathrm{N}$ fertilization, Azospirillum brasilense and Rhizobium tropici for the evaluated variables. However, isolated and/or combined effect of Mo was not observed. Seed inoculation with Azospirillum brasilense as well as their coinoculation with Rhizobium tropici in the absence of $\mathrm{N}$ fertilization was efficient to increase plant growth. Soil $\mathrm{N}$ fertilization at sowing was less efficient in promoting plant growth than when it was combined with seed inoculation with Rhizobium tropici.
\end{abstract}

\section{Crescimento do milho em resposta a Azospirillum brasilense, Rhizobium tropici, molibdênio e nitrogênio}

\section{R E S U M O}

Objetivou-se nesta pesquisa avaliar o efeito de Azospirillum brasilense, Rhizobium tropici, nitrogênio e molibdênio no crescimento do milho. $\mathrm{O}$ experimento foi realizado em casa de vegetação no período de outubro a novembro de 2015, no delineamento inteiramente casualizado em esquema fatorial $2 \times 2 \times 2 \times 5$, com 5 repetições considerando a ausência e a presença de Azospirillum brasilense, Rhizobium tropici, nitrogênio $\left(30 \mathrm{~kg} \mathrm{ha}^{-1}\right)$, além de cinco doses de molibdênio $\left(0 ; 7,5 ; 15,0 ; 22,5\right.$ e $\left.30,0 \mathrm{~g} \mathrm{ha}^{-1}\right)$. As variáveis avaliadas foram: altura, diâmetro basal do colmo, massas secas da parte aérea, raízes, total e nitrogênio acumulado na parte aérea. Verificou-se interação dupla ou tripla entre a adubação nitrogenada, Azospirillum brasilense e Rhizobium tropici para as variáveis avaliadas. Todavia, não foi observado efeito isolado e/ou combinado do molibdênio. Tanto a inoculação das sementes com Azospirillum brasiliense como a coinoculação deste com Rhizobium tropici na ausência de nitrogênio se mostraram eficientes para aumentar o crescimento das plantas. A adubação nitrogenada do solo na semeadura foi menos eficiente em promover o crescimento das plantas do que quando esta foi combinada com a inoculação das sementes com Rhizobium tropici. 


\section{INTRODUCTION}

Nitrogen $(\mathrm{N})$, despite being essential to maize growth and production, has problems related to its use due to the high cost of the fertilizers, low utilization by plants and probable environmental impacts. Seed inoculation with rhizobacteria, such as Azospirillum brasilense and Rhizobium tropici, can be an option to reduce the applied quantity and/or potentiate the effect of $\mathrm{N}$ fertilizers in the maize crop, since they are diazotrophic and thus can complement the quantity of the nutrient required by the plants via biological fixation of the atmospheric $\mathrm{N}$ (BNF). In addition, another benefit of these rhizobacteria is the action as plant-growth promoters (PGPR) through various mechanisms such as phosphate solubilization, production of phytohormones, siderophores, biocontrol of pathogens and pest insects (Carvalho et al., 2009; Hungria et al., 2010; Araújo et al., 2012).

Although bacteria of the genus Rhizobium have their beneficial effects normally reported for BNF in nodule-forming Fabaceae species, they can also act as PGPR in other plant species, colonizing the rhizosphere region without, however, forming nodules. Their isolate use (Mehboob et al., 2012) or combined with other rhizobacteria (Hahn et al., 2013) and with $\mathrm{N}$ fertilization (Dartora et al., 2016) has increased maize growth and production, indicating that the co-inoculation of microorganisms associated with chemical nutrients can be a promising technique.

Nitrogen utilization by maize can be potentiated by molybdenum (Mo), since it is a constituent of enzymes that allow the assimilation of this macronutrient via biological fixation by diazotrophic microorganisms (nitrogenase) and/or $\mathrm{N}$ fertilization (nitrate reductase). The increase in maize growth and production has already been observed with the use of Mo combined with Azospirillum brasilense (Ganapathy \& Savalgi, 2006) and $\mathrm{N}$ fertilizer (Valentini et al., 2005).

The combined use of chemical and biological inputs in agricultural crops can contribute to reduce costs and optimize the production. Therefore, this study aimed to dimension the magnitude of the effect of Azospirillum brasilense, Rhizobium tropici, Mo and $\mathrm{N}$ on maize growth.

\section{Material ANd Methods}

The experiment was conducted in a greenhouse located in the experimental area of the Federal University of Acre, in Rio Branco, Acre (9 $57^{\prime}$ S; 67 52’ W; 169 m), from October to November 2015, using the maize variety 'AL Bandeirante'. The experimental design was completely randomized, in 2 x $2 \times 2 \times 5$ factorial scheme, with 5 replicates, totaling 200 experimental units, which consisted of flexible polyethylene pots with capacity for $7 \mathrm{~L}$, height of $32.5 \mathrm{~cm}$ and area of 289 $\mathrm{cm}^{2}$. The factors corresponded to the absence and presence of Azospirillum brasilense, Rhizobium tropici and N (30 kg ha-1 of $\mathrm{N})$ and five Mo doses $\left(0 ; 7.5 ; 15.0 ; 22.5\right.$ and $\left.30.0 \mathrm{~g} \mathrm{ha}^{-1}\right)$, using urea $(45 \%$ of $\mathrm{N})$ and ammonium molybdate ( $54 \%$ of $\mathrm{Mo}$ ) as sources of $\mathrm{N}$ and $\mathrm{Mo}$, respectively.

The soil was collected from the superficial layer $(0-20 \mathrm{~cm})$ of an area under fallow and, after being placed in the pots, its fertility level was increased through phosphate fertilization using $100 \mathrm{mg}$ of $\mathrm{P}$ in the form of single superphosphate (18\% of $\mathrm{P}_{2} \mathrm{O}_{5}$ ) and potassium fertilization using $100 \mathrm{mg}$ of $\mathrm{K}$ in the form of potassium chloride $\left(58 \%\right.$ of $\left.\mathrm{K}_{2} \mathrm{O}\right)$, ten days prior to sowing. Soil physical and chemical analyses were carried out according to the methodologies proposed by EMBRAPA (1997). Before the experiment, the soil showed the following chemical attributes: $\mathrm{pH}\left(\mathrm{CaCl}_{2}\right)=5.6$; organic matter $=32.1 \mathrm{~g} \mathrm{dm}^{-3}$; $\mathrm{P}=35.9 \mathrm{mg} \mathrm{dm}^{-3} ; \mathrm{K}=93.8 \mathrm{mg} \mathrm{dm}^{-3} ; \mathrm{Ca}=4.15 \mathrm{cmol} \mathrm{dm}^{-3}$; $\mathrm{Mg}=1.49 \mathrm{cmol}_{\mathrm{c}} \mathrm{dm}^{-3} ; \mathrm{H}+\mathrm{Al}=1.7 \mathrm{cmol} \mathrm{dm}_{c}^{-3} ; \mathrm{S}=13.4 \mathrm{mg} \mathrm{dm}^{-3}$; $\mathrm{Fe}=284 \mathrm{mg} \mathrm{dm}^{-3} ; \mathrm{Zn}=3.1 \mathrm{mg} \mathrm{dm}^{-3} ; \mathrm{Cu}=2.1 \mathrm{mg} \mathrm{dm}^{-3} ;$ $\mathrm{Mn}=45.5 \mathrm{mg} \mathrm{dm}^{-3} ; \mathrm{B}=0.27 \mathrm{mg} \mathrm{dm}^{-3} ;$ sum of bases $=5.88 \mathrm{cmol} \mathrm{dm}^{-3}$; $\mathrm{CEC}=7.58 \mathrm{cmol}_{\mathrm{c}} \mathrm{dm}^{-3}$; base saturation $=77.57 \% ; \mathrm{Ca} / \mathrm{Mg}$ ratio $=2.79 ; \mathrm{Mg} / \mathrm{K}$ ratio $=6.11$. According to the granulometric characterization, the soil had $656 \mathrm{~g} \mathrm{~kg}^{-1}$ of sand, $77 \mathrm{~g} \mathrm{~kg}^{-1}$ of silt and $267 \mathrm{~g} \mathrm{~kg}^{-1}$ of clay. Apparent density corresponded to $1.44 \mathrm{~kg} \mathrm{dm}^{-3}$, particle density to $2.65 \mathrm{~kg} \mathrm{dm}^{-3}$ and total porosity to $45.66 \%$.

The sources of rhizobacteria were commercial peat inoculants based on Azospirillum brasilense, strains AbV5 and AbV6, and Rhizobium tropici, strains SEMIA 4077 and SEMIA 4088. Before utilization, the number of viable cells per unit of product was estimated through the serial dilution method and the colonies were counted on plates containing selective medium for Azospirillum composed of malic acid (5 g), dipotassium phosphate $(0.5 \mathrm{~g})$, iron sulfate $(0.5 \mathrm{~g})$, manganese $(0.01 \mathrm{~g})$ and magnesium $(0.2 \mathrm{~g})$, sodium chloride $(0.1 \mathrm{~g})$ and calcium $(0.02 \mathrm{~g})$, sodium molybdate $(0.002 \mathrm{~g})$, bromothymol blue $(0.002 \mathrm{~g})$, agar-agar $(20 \mathrm{~g})$, potassium hydroxide $(4 \mathrm{~g})$ and distilled water $(1000 \mathrm{~mL})$. The selective medium for Rhizobium was composed of mannitol (10 g), yeast extract (1 g), sodium chloride $(0.1 \mathrm{~g})$, magnesium sulfate $(0.2 \mathrm{~g})$, dipotassium phosphate $(0.5 \mathrm{~g})$ bacteriological agar $(20 \mathrm{~g})$ and distilled water $(1000 \mathrm{~mL})$. The results of the counts indicated the presence of $1.1 \times 10^{9}$ viable cells of Azospirillum brasilense $\mathrm{g}^{-1}$ of inoculant and $1.5 \times 10^{9}$ viable cells of Rhizobium tropici $\mathrm{g}^{-1}$ of inoculant.

In the treatments defined by the presence of Rhizobium tropici, Azospirillum brasilense and Mo doses, the procedures of bacterial inoculation, co-inoculation and Mo application in the maize seeds were carried out during the installation of the experiment, in a period with mild temperature to minimize its effect on microorganism survival. $100 \mathrm{~g}$ of seeds received, separately and/or combined, the application of $0.61 \mathrm{~g}$ peat inoculant based on Azospirillum brasilense; $0.61 \mathrm{~g}$ of peat inoculant based on Rhizobium tropici; and 0.07, 0.14, 0.21 and $0.28 \mathrm{~g}$ of ammonium molybdate. These quantities were established based on the doses of $100 \mathrm{~g}$ of inoculant for 60000 seeds and 7.5, 15, 22.5 and $30 \mathrm{~g} \mathrm{Mo} \mathrm{ha}^{-1}$. To guarantee greater adhesion and uniform distribution of the inoculants and ammonium molybdate, the seeds were moistened with $10 \%$ sugary solution (Brandão Júnior \& Hungria, 2000) at dose of $0.6 \mathrm{~mL} 100 \mathrm{~g}^{-1}$ of seeds.

After the products were applied on the seeds and dried in the shade, sowing was immediately performed using five seeds per experimental unit at standard depth of $2 \mathrm{~cm}$. For the treatments with presence of $\mathrm{N}$, the experimental units received $0.19 \mathrm{~g}$ of urea, which was manually incorporated to the soil at depth of approximately $3 \mathrm{~cm}$, at sowing. 
In the V3 phenological stage, thinning was performed to maintain only the most vigorous plant in each experimental unit. Irrigations were manually applied, in a regular and homogeneous way, to maintain soil moisture close to $70 \%$ of field capacity.

During the experiment, temperature and relative air humidity inside the greenhouse were monitored using a data logger. Soil temperature was daily measured using a stem thermometer, at depth of $14 \mathrm{~cm}$. Minimum mean values of temperature and air humidity corresponded to $24^{\circ} \mathrm{C}$ and $40 \%$, and maximum mean values to $42{ }^{\circ} \mathrm{C}$ and $94 \%$. The mean temperature in the soil along the experimental period was $35^{\circ} \mathrm{C}$.

The experiment was evaluated with at least $50 \%$ of the plants were in the phenological stage of twelve fully developed leaves, considering the following growth variables: plant height $(\mathrm{PH})$, basal stem diameter (BSD), shoot dry matter (SDM), root dry matter (RDM), total dry matter (TDM) and $\mathrm{N}$ accumulated in the shoots (NAS).

Plant height was measured from the base to the insertion of the flag leaf, using a measuring tape. Basal stem diameter was measured using a manual caliper. Plant shoots were collected through a cut in the collar region; subsequently, plants were cleaned through washing in running water on sieves. The collected material was dried in an oven at $65^{\circ} \mathrm{C}$ until constant weight to obtain SDM, RDM and, with their sum, TDM. The dried material was ground to determine NAS through wet digestion, according to the Kjeldahl method as described by Tedesco et al. (1995).

The initial statistical analysis of the results consisted in observing the presence of discrepant data (Grubbs, 1969), error normality (Shapiro \& Wilk, 1965) and homogeneity of variances (Bartlett, 1937). The F test of the analysis of variance was used to determine the significance of the isolated or combined effects of the treatments. For the significant interactions $(\mathrm{p}<0.05)$, a follow-up analysis was conducted to evaluate the effect of the levels of a factor with respect to another. For Mo, regression and orthogonal contrast (Nogueira, 2004) analyses were also conducted to evaluate the effect of its absence compared with its presence, regardless of the dose. The analyses were carried out using the statistical program Sisvar (Ferreira, 2011).

\section{Results AND Discussion}

Seed inoculation with Azospirillum brasilense in the absence of $\mathrm{N}$ incremented maize growth, causing increase in RDM, TDM and NAS (Table 1). On the other hand, in the presence of $\mathrm{N}$ fertilization, Azospirillum brasilense inoculation did not interfere with these variables. These results evidence the importance of seed inoculation with Azospirillum brasilense, especially when $\mathrm{N}$ fertilization is not applied; in this case, it is possible to increase total plant growth by $33 \%$ and the accumulated content $\mathrm{N}$ by $30 \%$. Therefore, Azospirillum brasilense allowed to reduce plant demand for $\mathrm{N}$ fertilizer at sowing, but did not potentiate the effect of the fertilization. Sangoi et al. (2015) also did not observe interference of Azospirillum brasilense in maize when combined with $\mathrm{N}$ fertilization.
Table 1. Root dry matter (RDM) and total dry matter (TDM) of maize plants and nitrogen accumulated in the shoots (NAS) as a function of the interaction between Azospirillum brasilense and nitrogen

\begin{tabular}{ccrrr}
\hline \multirow{2}{*}{ Variables } & Azospirillum & \multicolumn{2}{c}{ Nitrogen } & \multirow{2}{*}{ CV } \\
\cline { 3 - 4 } & brasilense & Absence & Presence & (\%) \\
\cline { 3 - 4 } RDM $(\mathrm{g})$ & Absence & $18.81 \mathrm{Bb}$ & $25.87 \mathrm{Aa}$ & 25.75 \\
& Presence & $25.58 \mathrm{Aa}$ & $27.66 \mathrm{Aa}$ & \\
& Absence & $37.75 \mathrm{Bb}$ & $52.02 \mathrm{Aa}$ & \\
TDM $(\mathrm{g})$ & Presence & $50.16 \mathrm{Ab}$ & $55.28 \mathrm{Aa}$ & \\
& Absence & $199.31 \mathrm{Bb}$ & $281.49 \mathrm{Aa}$ & \\
\multirow{2}{*}{ NAS $(\mathrm{mg})$} & Presence & $258.27 \mathrm{Aa}$ & $276.00 \mathrm{Aa}$ & 22.68 \\
\hline
\end{tabular}

Means followed by the same letter, uppercase in the column and lowercase in the row, do not differ $(p>0.05)$ by F test

The increase of RDM, TDM and NAS due to the presence of Azospirillum brasilense is probably related to phosphate solubilization and/or production of phytohormones by these microorganisms, such as auxins, gibberellins and cytokinins, which evidences the effect of this rhizobacterium as plant growth promoter. Pedrinho et al. (2010), in a study on the activity of microorganisms in maize rhizosphere, observed phosphate solubilization and production of indole acetic acid (IAA) by bacteria of the genus Azospirillum. The increment of variables related to maize growth due to the isolated use of Azospirillum brasilense or combined use with $\mathrm{N}$ and/or other bacterial species has already been reported by Hungria et al. (2010), Dartora et al. (2013), Hahn et al. (2013), Mazzuchelli et al. (2014) and Marini et al. (2015).

The combined effect of $\mathrm{N}$ with Rhizobium tropici inoculation in the seeds led to increment in RDM, TDM and NAS (Table 2). Although in nodule-forming species of the Fabaceae family, such as soybean and common bean, $\mathrm{N}$ fertilization normally limits the diazotrophic activity of the rhizobia, in maize, on the contrary, there was a synergistic effect of Rhizobium tropici and the $\mathrm{N}$ fertilizer, allowing an increase of $34 \%$ in total plant growth and $37 \%$ in the $\mathrm{N}$ content accumulated in the shoots. These results indicate that, when $\mathrm{N}$ fertilization is applied and maize seeds are inoculated with Rhizobium tropici, plants benefit from both the $\mathrm{N}$ supplied via fertilizer and $\mathrm{N}$ derived from the diazotrophic activity of this microorganism. Bécquer et al. (2011) and Hahn et al. (2013) also observed maize growth promotion by rhizobia, but in the absence of $\mathrm{N}$ fertilization. On the other hand, Dartora et al. (2016) reported that the use of Rhizobium sp. associated with $30 \mathrm{~kg} \mathrm{ha}^{-1}$ of $\mathrm{N}$ at maize sowing resulted in yield equivalent to that obtained with the application of $160 \mathrm{~kg} \mathrm{ha}^{-1}$ of $\mathrm{N}$ fertilizer.

Table 2. Root dry matter (RDM) and total dry matter (TDM) of maize plants and nitrogen accumulated in the shoots (NAS) as a function of the interaction between Rhizobium tropici and nitrogen

\begin{tabular}{ccrrc}
\hline \multirow{2}{*}{ Variables } & Rhizobium & \multicolumn{2}{c}{ Nitrogen } & CV \\
\cline { 3 - 4 } & tropici & Absence & Presence & (\%) \\
\cline { 3 - 4 } RDM (g) & Absence & $23.46 \mathrm{Aa}$ & $25.65 \mathrm{Aa}$ & 25.75 \\
& Presence & $20.94 \mathrm{Ab}$ & $27.88 \mathrm{Aa}$ & \\
& Absence & $46.35 \mathrm{Ab}$ & $51.45 \mathrm{Ba}$ & \\
TDM (g) & Presence & $41.56 \mathrm{Bb}$ & $55.85 \mathrm{Aa}$ & \\
& Absence & $239.76 \mathrm{Aa}$ & $260.01 \mathrm{Ba}$ & \\
\multirow{2}{*}{ NAS (mg) } & Presence & $217.83 \mathrm{Ab}$ & $297.48 \mathrm{Aa}$ & 22.68 \\
\hline
\end{tabular}

Means followed by the same letter, uppercase in the column and lowercase in the row, do not differ $(p>0.05)$ by F test 
Maize seed inoculation with Azospirillum brasilense in the presence or absence of $\mathrm{N}$, combined or not with Rhizobium tropici, promoted increment in $\mathrm{PH}$ and SDM. The association of Azospirillum brasilense with $\mathrm{N}$ or Rhizobium tropici also increased BSD (Table 3). These growth variables are considered as determinant for the production of the plants, evidencing the beneficial effects of this microbial species. Marini et al. (2015) and Quadros et al. (2014) also reported that Azospirillum brasilense caused increase in the shoot dry matter of maize plants. However, Cunha et al. (2014) and Morais et al. (2015) did not observe increase in plant height or stem diameter in response to maize seed inoculation with Azospirillum brasilense.

Maize seed co-inoculation with Azospirillum brasilense and Rhizobium tropici in the absence of $\mathrm{N}$ increased $\mathrm{PH}, \mathrm{BSD}$ and SDM, indicating the occurrence of synergism between these microbial species in benefit of plant growth. In contrast, when $\mathrm{N}$ fertilization was applied, the simultaneous inoculation of the rhizobacteria caused reduction $(\mathrm{PH})$ or did not interfere (BSD, SDM) in these variables. These results demonstrate that, when the seeds are co-inoculated and $\mathrm{N}$ fertilization is not applied, PH, BSD and SDM can be increased by 24,11 and 35\%, respectively (Table 3 ). Positive results of increment of height, stem diameter and shoot dry matter in maize were observed by Mazzuchelli et al. (2014), for simultaneous use of Bacillus subtilis and Azospirillum brasilense, and by Dartora et al. (2013), for the association of Azospirillum brasilense and Herbaspirillum seropedicae. In addition, Marks et al. (2015) conducted a study about inoculation of Azospirillum brasilense and Rhizobium tropici metabolites in maize and observed increase in shoot dry matter, grain yield and $\mathrm{N}$ accumulation. The authors also attributed these results to the metabolites that are produced by rhizobia and act in the promotion of plant growth.

There was reduction of height, basal stem diameter and shoot dry matter of maize in the presence of Rhizobium tropici and in the absence of Azospirillum brasilense and N. However, in the presence of $\mathrm{N}$ and absence of Azospirillum brasilense, the Rhizobium tropici promoted increase in PH and SDM (Table 3), evidencing the importance of $\mathrm{N}$ as enhancer of the activity of this species, which was reflected in plant growth. Although rhizobia

Table 3. Plant height (PH), basal stem diameter (BSD) and shoot dry matter (SDM) of maize plants as a function of the interaction between Azospirillum brasilense, Rhizobium tropici and nitrogen

\begin{tabular}{|c|c|c|c|c|c|}
\hline \multirow[b]{2}{*}{ Variables } & \multicolumn{2}{|c|}{ Rhizobacteria } & \multicolumn{2}{|c|}{ Nitrogen } & \multirow[b]{2}{*}{$\begin{array}{l}\text { CV } \\
(\%)\end{array}$} \\
\hline & $\begin{array}{l}\text { Azospirillum } \\
\text { brasilense }\end{array}$ & $\begin{array}{c}\text { Rhizobium } \\
\text { tropici }\end{array}$ & Absence & Presence & \\
\hline \multirow{4}{*}{$\mathrm{PH}(\mathrm{cm})$} & Absence & Absence & $49.21 \mathrm{Bb} \underline{\mathrm{A}}$ & $53.35 \mathrm{BaB}$ & \multirow{4}{*}{10.85} \\
\hline & Presence & Absence & 55.73 Aaa & 57.22 Aaa & \\
\hline & Absence & Presence & $44.68 \mathrm{Bb} \underline{\mathrm{B}}$ & $59.97 \mathrm{Aa} \underline{\mathrm{A}}$ & \\
\hline & Presence & Presence & 55.40 Aaa & $56.08 \mathrm{Baa}$ & \\
\hline \multirow{4}{*}{$\mathrm{BSD}(\mathrm{cm})$} & Absence & Absence & $1.20 \mathrm{Aa} \underline{\bar{A}}$ & $1.20 \mathrm{Ba} \underline{A}$ & \multirow{4}{*}{14.71} \\
\hline & Presence & Absence & $1.26 \mathrm{Aa} \underline{\mathrm{a}}$ & $1.30 \mathrm{Aa} \underline{\mathrm{a}}$ & \\
\hline & Absence & Presence & $1.09 \mathrm{Bb} \underline{\mathrm{B}}$ & $1.30 \mathrm{Aa} \underline{\mathrm{A}}$ & \\
\hline & Presence & Presence & $1.21 \mathrm{Aa} \underline{a}$ & $1.26 \mathrm{Aa} \underline{a}$ & \\
\hline \multirow{4}{*}{ SDM (g) } & Absence & Absence & $19.91 \mathrm{Bb} \underline{A}$ & 23.97 Baㅡㅡㅁ & \multirow{4}{*}{17.36} \\
\hline & Presence & Absence & 25.47 Aaa & $27.63 \mathrm{Aaa}$ & \\
\hline & Absence & Presence & $17.56 \mathrm{Bb} \underline{\mathrm{B}}$ & $28.26 \mathrm{Aa} \underline{A}$ & \\
\hline & Presence & Presence & $23.68 \mathrm{Ab} \underline{a}$ & $27.59 \mathrm{Aaa}$ & \\
\hline
\end{tabular}

For a same variable, means followed by the same letter, uppercase in the column, lowercase in the row, underlined uppercase in the column for the first and third means and underlined lowercase for the second and fourth means, do not differ $(p>0.05)$ by F test are recommended for biological $\mathrm{N}$ fixation in nodule-forming Fabaceae species, they can act as growth promoters in other plant species, including Poaceae, such as maize. Tan et al. (2014) observed greater growth of rice through the action of different species of rhizobacteria, including those of the genus Rhizobium.

When $\mathrm{N}$ fertilization was applied in the presence of inoculation with Rhizobium tropici and absence of Azospirillum brasilense, there were increases of $34 \%$ in $\mathrm{PH}, 19 \%$ in BSD and $61 \%$ in SDM (Table 3); however, when the seeds were not inoculated, $\mathrm{N}$ fertilization increased $\mathrm{PH}$ by $8 \%$, SDM by $20 \%$ and did not interfere with BSD. These results indicate that the use of $\mathrm{N}$ fertilizer at sowing combined with Rhizobium tropici inoculation of maize seeds is more efficient than the isolated application of $\mathrm{N}$ fertilizer in the soil.

Considering the positive effect on maize growth due to the inoculation of seeds with Azospirillum brasilense in the absence of Rhizobium tropici and presence of $\mathrm{N}$, and also when Rhizobium tropici was applied in the absence of Azospirillum brasilense and presence of $\mathrm{N}$ (Table 3 ), it is possible to note, due to the increment in $\mathrm{PH}, \mathrm{BSD}$ and SDM, that for both combinations the activity of these inoculated rhizobacteria was potentiated by the use of the $\mathrm{N}$ fertilizer at sowing.

Mo fertilization of up to $30 \mathrm{~g} \mathrm{ha}^{-1}$, isolated or combined with Azospirillum brasilense, Rhizobium tropici and $\mathrm{N}$ did not interfere with the evaluated growth variables of maize. Since Mo is a micronutrient, its requirement by maize and other plant species is low (Favarin et al., 2008). Thus, the contents of this element available in the soil and in the seeds were probably sufficient to meet the requirement of the plants.

\section{Conclusions}

1. Azospirillum brasilense, in the absence of $\mathrm{N}$ fertilizer, promotes increase in plant growth and $\mathrm{N}$ accumulation in the maize variety 'AL Bandeirante'.

2. Rhizobium tropici potentiates the effect of $\mathrm{N}$ fertilization on the maize variety 'AL Bandeirante'.

3. Co-inoculation of Azospirillum brasilense and Rhizobium tropici, in the absence of $\mathrm{N}$ fertilizer, increases the growth of the variety 'AL Bandeirante'.

4. Molybdenum fertilization of up to $30 \mathrm{~g} \mathrm{ha}^{-1}$, isolated or combined with Azospirillum brasilense, Rhizobium tropici and nitrogen, do not interfere with the growth of the maize variety 'AL Bandeirante'.

\section{Literature Cited}

Araújo, F. F. de; Guaberto, L. M.; Silva, I. F. da. Bioprospecção de rizobactérias promotoras de crescimento em Brachiaria brizantha. Revista Brasileira de Zootecnia, v.41, p.521-527, 2012. https://doi. org/10.1590/S1516-35982012000300007

Bartlett, M. S. Properties of sufficiency and statistical tests. Proceedings of the Royal Society of London, v.160, p.268-282, 1937. https://doi.org/10.1098/rspa.1937.0109

Bécquer, C. J.; Salas, B.; Ávila, U.; Palmero, L.; Nápoles, J. A.; Ulloa, L.; Suárez, Y.; Colina, O. L. Selection of Rhizobium strains, inoculated in corn (Zea mays, L.), in field conditions in cattle ecosystems of Sancti Spiritus, Cuba. Cuban Journal of Agricultural Science, v.45, p.445-449, 2011. 
Brandão Júnior, O.; Hungria, M. Efeito de concentrações de solução açucarada na aderência do inoculante turfoso às sementes, na nodulação e no rendimento da soja. Revista Brasileira de Ciência do Solo, v.24, p.515-526, 2000. https://doi.org/10.1590/S010006832000000300005

Carvalho, D. D. C.; Oliveira, D. F.; Pasqual, M.; Campos, V. P. Rizobactérias produtoras de promotores do crescimento de plantas. Pesquisa Agropecuária Tropical, v.39, p.338-341, 2009.

Cunha, F. N.; Silva, N. F. da; Bastos, F. J. de C.; Carvalho, J. J. de; Moura, L. M. de F.; Teixeira, M. B.; Rocha, A. C. da; Souchie, E. L. Efeito da Azospirillum brasilense na produtividade de milho no sudoeste goiano. Revista Brasileira de Milho e Sorgo, v.13, p.261-272, 2014. https://doi.org/10.18512/1980-6477/rbms.v13n3p261-272

Dartora, J.; Guimarães, V. F.; Marini, D.; Sander, G. Adubação nitrogenada associada à inoculação com Azospirillum brasilense $\mathrm{e}$ Herbaspirillum seropedicae na cultura do milho. Revista Brasileira de Engenharia Agrícola e Ambiental, v.17, p.1023-1029, 2013. https://doi.org/10.1590/S1415-43662013001000001

Dartora, J.; Guimarães, V. F.; Menezes, C. R. J.; Freiberger, M. B.; Castoldi, G.; Gonçalves, E. D. V. Maize response to inoculation with strains of plant growth-promoting bacteria. Revista Brasileira de Engenharia Agrícola e Ambiental, v.20, p.606-611, 2016. https://doi.org/10.1590/1807-1929/agriambi.v20n7p606-611

EMBRAPA - Empresa Brasileira de Pesquisa Agropecuária. Manual de métodos de análise de solo. 2.ed. Rio de Janeiro: Embrapa Solos, 1997. 212p.

Favarin, J. L.; Tezotto, T.; Ragassi, C. F. Uso racional de micronutrientes na cultura de milho. Piracicaba: International Plant Nutrition Institute, 2008. 8p. Informações Agronômicas, 122

Ferreira, D. F. Sisvar: A computer statistical analysis system. Ciência e Agrotecnologia, v.35, p.1039-1042, 2011. https://doi.org/10.1590/ S1413-70542011000600001

Ganapathy, B. A.; Savalgi, V. P. Effect of micronutrients on the performance of Azospirillum brasilense on the nutrient uptake, growth and yield in maize crop. Karnataka Journal of Agricultural Sciences, v.19, p.66-70, 2006.

Grubbs, F. E. Procedures for detecting outlying observations in samples. Technometrics, v.11, p.1-21, 1969. https://doi.org/10.1 080/00401706.1969.10490657

Hahn, L.; Sá, E. L. S. de; Silva, W. R. da; Machado, R. G.; Damasceno, R. G. Promoção de crescimento de híbridos de milho inoculados com rizóbios e bactérias diazotróficas associativas. Pesquisa Agropecuária Gaúcha, v.19, p.33-40, 2013.

Hungria, M.; Campo, R. J.; Souza, E. M.; Pedrosa, F. O. Inoculation with selected strains of Azospirillum brasilense and A. lipoferum improves yields of maize and wheat in Brazil. Plant and Soil, v.331, p.413-425, 2010. https://doi.org/10.1007/s11104-009-0262-0

Marini, D.; Guimarães, V. F.; Dartora, J.; Lana, M. do C.; Pinto Júnior, A. S. Growth and yield of corn hybrids in response to association with Azospirillum brasilense and nitrogen fertilization. Revista Ceres, v.62, p.117-123, 2015. https://doi.org/10.1590/0034$737 \mathrm{X} 201562010015$
Marks, B. B.; Megías, M.; Ollero, F. J.; Nogueira, M. A.; Araújo, R. S.; Hungria, M. Maize growth promotion by inoculation with Azospirillum brasilense and metabolites of Rhizobium tropici enriched on lipo-chitooligosaccharides (LCOs). AMB Express, v.5, p.71-81, 2015. https://doi.org/10.1186/s13568-015-0154-Z

Mazzuchelli, R. de C. L.; Sossai, B. F.; Araújo, F. F. de. Inoculação de Bacillus subtilis e Azospirillum brasilense na cultura do milho. Colloquium Agrariae, v.10, p.40-47, 2014. https://doi.org/10.5747/ ca.2014.v10.n2.a106

Mehboob, I.; Zahir, Z. A.; Arshad, M.; Tanveer, A.; Khalid, M. Comparative effectiveness of different Rhizobium sp. for improving growth and yield of maize (Zea mays L.). Soil Environmental, v.31, p.37-46, 2012.

Morais, T. P. de; Brito, C. H. de; Ferreira, A. de S.; Luz, J. M. Q. Aspectos morfofisiológicos de plantas de milho e bioquímico do solo em resposta à adubação nitrogenada e à inoculação com Azospirillum brasilense. Revista Ceres, v.62, p.507-509, 2015. https://doi.org/10.1590/0034-737X201562060012

Nogueira, M. C. S. Orthogonal contrasts: Definitions and concepts. Scientia Agrícola, v.61, p.118-124, 2004. https://doi.org/10.1590/ S0103-90162004000100020

Pedrinho, E. A. N.; Galdiano Júnior, R. F.; Campanharo, J. C.; Alves, L. M. C.; Lemos, E. G. de M. Identificação e avaliação de rizobactérias isoladas de raízes de milho. Bragantia, v.69, p. 905-911, 2010. https://doi.org/10.1590/S0006-87052010000400017

Quadros, P. D. de; Roesch, L. F. W.; Silva, P. R. F. da; Vieira, V. M.; Roehrs, D. D.; Camargo, F. A. de O. Desempenho agronômico a campo de híbridos de milho inoculados com Azospirillum. Revista Ceres, v.61, p.209-218, 2014. https://doi.org/10.1590/ S0034-737X2014000200008

Sangoi, L.; Silva, L. M. M. da; Mota, M. R.; Panison, F.; Schmitt, A.; Souza, N. M. de; Giordani, W.; Schenatto, D. E. Desempenho agronômico do milho em razão do tratamento de sementes com Azospirillum sp. e da aplicação de doses de nitrogênio mineral. Revista Brasileira de Ciência do Solo, v.39, p.1141-1150, 2015. https://doi.org/10.1590/01000683rbcs20140736

Shapiro, S. S.; Wilk, M. B. An analysis of variance test for normality. Biometrika, v.52, p.591-611, 1965. https://doi.org/10.1093/ biomet/52.3-4.591

Tan, K. Z.; Radziah, O.; Halimi, M. S.; Khairuddin, A. R.; Habib, S. H.; Shamsuddin, Z. H. Isolation and characterization of rhizobia and plant growth-promoting rhizobacteria and their effects on growth of rice seedlings. American Journal of Agricultural and Biological Sciences, v.9, p.342-360, 2014. https://doi.org/10.3844/ ajabssp.2014.342.360

Tedesco, J. M.; Gianello, C.; Bissani, A. C.; Bohlen, H.; Volkweiss, S. J. Análise de solo, plantas e outros materiais. 2.ed. Porto Alegre: UFRS, 1995. 174 p. Boletim Técnico, 5

Valentini, L.; Coelho, F. C.; Ferreira, M. dos S. Teor de nitrogênio foliar e produtividade de três cultivares de milho (Zea mays L.) submetidos às adubações nitrogenada e molíbdica. Revista Ceres, v.52, p.567-577, 2005. 